\title{
SSH2 wt Allele
}

National Cancer Institute

\section{Source}

National Cancer Institute. SSH2 wt Allele. NCI Thesaurus. Code C114425.

Human SSH2 wild-type allele is located in the vicinity of $17 q 11.2$ and is approximately 304 $\mathrm{kb}$ in length. This allele, which encodes protein phosphatase Slingshot homolog 2 protein, is involved in both the dephosphorylation of proteins and the modulation of actin filament formation. 